\title{
STRATEGIC CONCEPTS
}




\section{Strategic Concepts}

CLIVE SUTTON

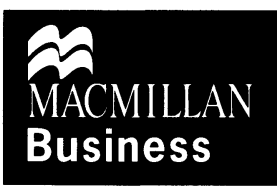


(C) Clive Sutton 1998

Softcover reprint of the hardcover 1st edition 1998

All rights reserved. No reproduction, copy or transmission of this publication may be made without written permission.

No paragraph of this publication may be reproduced, copied or transmitted save with written permission or in accordance with the provisions of the Copyright, Designs and Patents Act 1988, or under the terms of any licence permitting limited copying issued by the Copyright Licensing Agency, 90 Tottenham Court Road, London W1P 9HE.

Any person who does any unauthorised act in relation to this publication may be liable to criminal prosecution and civil claims for damages.

The author has asserted his right to be identified as the author of this work in accordance with the Copyright, Designs and Patents Act 1988.

First published 1998 by

MACMILLAN PRESS LTD

Houndmills, Basingstoke, Hampshire RG21 6XS

and London

Companies and representatives

throughout the world

ISBN 978-0-333-72530-6 ISBN 978-1-349-26670-8 (eBook)

DOI 10.1007/978-1-349-26670-8

A catalogue record for this book is available from the British Library.

$\begin{array}{rrrrrrrrrr}10 & 9 & 8 & 7 & 6 & 5 & 4 & 3 & 2 & 1\end{array}$

$\begin{array}{llllllllll}07 & 06 & 05 & 04 & 03 & 02 & 01 & 00 & 99 & 98\end{array}$

Copy-edited and typeset by Povey-Edmondson

Tavistock and Rochdale, England 


\section{Contents}

List of Figures $\quad$ ix

Preface $\quad$ xi

1 The Nature of Strategic Thinking 1

$\begin{array}{lr}\text { INTRODUCTION } & 1 \\ \text { An Example: The Daimler-Benz Group } & 1 \\ \text { STRATEGY, CHOICE AND UNCERTAINTY } & 2 \\ \text { Strategic Choice } & 3 \\ \text { Uncertainty } & 4 \\ \text { OBJECTIVES } & 5 \\ \text { The Time Horizon } & 5 \\ \text { The Nature of a Firm's Objectives } & 7 \\ \text { Objectives and Proxies } & 8 \\ \text { Multiple Objectives } & 8 \\ \text { STRATEGIC ANALYSIS } & 10 \\ \text { Characteristics } & 11 \\ \text { Context } & 12 \\ \text { Choice } & 13 \\ \text { STRATEGIC MODES } & 14 \\ \text { TENSIONS IN STRATEGIC THINKING } & 16 \\ \text { Size } & 17 \\ \text { Supply Chains } & 17 \\ \text { Diversity } & 17 \\ \text { Innovation } & 18 \\ \text { Mergers } & 19 \\ \text { Networks } & 19 \\ \text { Summary } & 20\end{array}$

2 Developments in Strategic Thinking 21

$\begin{array}{ll}\text { INTRODUCTION } & 21\end{array}$

PHASE 1: THE DOMINANCE OF TECHNOLOGY 22

Large Size $\quad 22$

Growth and Diversification 24

PHASE 2: THE SEARCH FOR QUALITY

Quality of Output 27

A Balanced Portfolio 28

Competitive Forces $\quad 29$ 
PHASE 3: LEANNESS AND COMPETITION $\quad 30$

Global Changes in Competition $\quad 30$

Lean Production $\quad 31$

Firms' Conduct Versus Industrial Structure $\quad 32$

Niche Markets and Mobility Barriers $\quad 34$

PHASE 4: RESPONSIVENESS AND INNOVATION

Continuous Innovation $\quad 35$

A Lean Portfolio 36

OVERVIEW: THREE ELEMENTS

$\begin{array}{ll}\text { Focus } & 37\end{array}$

Flexibility $\quad 37$

$\begin{array}{ll}\text { Future } & 38\end{array}$

3 Size and Rationalisation $\quad 39$

$\begin{array}{ll}\text { INTRODUCTION } & 39\end{array}$

ENDURING ADVANTAGES OF SIZE $\quad 39$

Economies of Scale $\quad 39$

Stature $\quad 41$

PROBLEMS OF SIZE $\quad 42$

Technical and Market Factors $\quad 42$

Behavioural Factors $\quad 43$

Behavioural Examples $\quad 45$

RESTRUCTURING AND RE-ENGINEERING $\quad 47$

Restructuring in Principle $\quad 47$

Restructuring in Practice $\quad 48$

DELAYERING - SOME RESERVATIONS $\quad 50$

Incentives $\quad 50$

Corporate Memory $\quad 50$

Co-ordination $\quad 52$

SMALL FIRMS - CHARACTERISTICS $\quad 52$

Size and Scale $\quad 53$

Diversity $\quad 53$

Risk of Failure $\quad 54$

Agglomeration $\quad 55$

SMALL FIRMS - STRATEGIC CONSIDERATIONS

Strategic Advantages $\quad 55$

Minimising Disadvantages $\quad 58$

$\begin{array}{ll}\text { Outcomes } & 58\end{array}$

$\begin{array}{ll}\text { SYMBIOSIS } & 60\end{array}$

4 Supply Chain Co-ordination $\quad 62$

INTRODUCTION $\quad 62$

THE MAIN ISSUES $\quad 62$ 
The Nature of Supply Chains

Depth and Breadth of Integration 63

THE CHOICE: OUTSOURCING OR INTEGRATION?

The Trade-Off

Transaction Costs $\quad 65$

Informal Constraints $\quad 68$

Summary 69

THE DECLINE OF VERTICAL INTEGRATION

$\begin{array}{ll}\text { General Changes } & 70\end{array}$

Special Claims $\quad 71$

$\begin{array}{ll}\text { OUTSOURCING } & 78\end{array}$

$\begin{array}{ll}\text { Limitations } & 78\end{array}$

Transition from Integration to Outsourcing $\quad 80$

Strategic implications $\quad 81$

$\begin{array}{ll}\text { Virtual Firms } & 82\end{array}$

5 Specialisation and Diversification $\quad 83$

INTRODUCTION

REDUCTIONS IN SCOPE $\quad 83$

Excessive Diversity $\quad 83$

An Optimum Level of Diversification $\quad 84$

Growth Beyond the Optimum $\quad 85$

Environmental Changes $\quad 86$

THE CONTINUED SIGNIFICANCE OF DIVERSIFICATION

$\begin{array}{ll}\text { Asia } & 88\end{array}$

Western Firms $\quad 88$

A Question of Balance $\quad 90$

THE RESOURCES NEEDED FOR DIVERSIFICATION 92

Evaluating Resources $\quad 92$

Accumulation and Resource Leverage $\quad 95$

Applying Resources 96

RESOURCES AND OPPORTUNITIES FOR DIVERSIFICATION 97

Internal Development of Resources $\quad 98$

External Changes and New Opportunities 101

$\begin{array}{ll}\text { Synergy } & 104\end{array}$

WEAKNESS AND THREATS 107

$\begin{array}{ll}\text { The Search for a Solution } & 107\end{array}$

Combined Threats and Opportunities 108

$\begin{array}{ll}\text { The Search for Opportunities } & 110\end{array}$

6 Innovation and Imitation 111

INTRODUCTION 111

THE NATURE OF INNOVATION 
Categories: Products, Processes and Services 111

$\begin{array}{ll}\text { Innovation and Technical Progress } & 112\end{array}$

$\begin{array}{ll}\text { Risks and Errors } & 113\end{array}$

The Rate of Adoption $\quad 114$

THE STRATEGIC ROLE OF INNOVATION 115

$\begin{array}{ll}\text { Acceleration } & 115\end{array}$

The Classical Approach $\quad 116$

The Modernist Approach 116

A Post-Modernist Approach $\quad 118$

$\begin{array}{ll}\text { PIONEERS AND IMITATORS } & 120\end{array}$

Imitative Strategies $\quad 120$

Gains from Pioneering: The Evidence 121

Conditions for Success $\quad 122$

$\begin{array}{ll}\text { LARGE AND SMALL FIRMS IN INNOVATION } & 127\end{array}$

$\begin{array}{ll}\text { Strategic Considerations for Small Firms } & 127\end{array}$

Complementarity Between Large and Small Firms 130

7 Divestment, Mergers and Strategic Alliances 133

$\begin{array}{lr}\text { INTRODUCTION } & 133 \\ & 133\end{array}$

DIVESTMENT 133

General Considerations $\quad 133$

$\begin{array}{ll}\text { Trade Sales } & 136\end{array}$

Demerger $\quad 138$

Management Buyouts $\quad 139$

MERGERS AND INTERNAL GROWTH 142

Internal Growth 143

External Growth $\quad 148$

STRATEGIC ALLIANCES $\quad 155$

The Nature of Alliances $\quad 155$

Potential Problems $\quad 156$

Potential Benefits $\quad 157$

$\begin{array}{ll}\text { Trends and Cases } & 158\end{array}$

8 Summary and Conclusion 162

Concentration $\quad 162$

Customers $\quad 163$

$\begin{array}{ll}\text { Co-operation } & 163\end{array}$

Competition $\quad 163$

$\begin{array}{ll}\text { Continuity } & 164\end{array}$

$\begin{array}{ll}\text { Bibliography } & 165\end{array}$

$\begin{array}{ll}\text { Index } & 170\end{array}$ 


\section{List of Figures}

1.1 The focus for strategic analysis 10

2.1 Growth/share matrix 28

2.2 Competitive forces 30

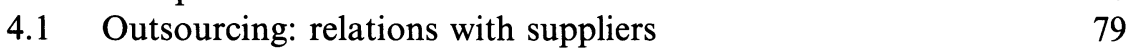

$\begin{array}{ll}7.1 & \text { Alternative growth paths }\end{array}$ 


\section{Preface}

Contemporary corporate strategy has seen a plethora of instant solutions such as re-engineering, outsourcing or continuous innovation, and earlier strategies based on scale or scope have been rejected in favour of a clear focus on core activities. This book attempts to present a balance which sets these strategic trends in their historical context and assesses their current relevance. After a general introduction it considers size (re-engineering), integration (outsourcing), diversification (focus), innovation (continuous and discontinuous) and mergers, together with divestment and strategic alliances. In each case the topics are considered as a series of options and not as strategic imperatives.

The book therefore focuses on broad notions of strategy and on strategic thinking. It is a book about thinking rather than doing - although I dare to hope that practitioners may still find something here to interest them. It is intended primarily as a textbook for undergraduate programmes in Business Studies or Business Administration, which universally include course units in Business Strategy as a unifying or contextual theme, and it should also serve as an introductory text for those students at Diploma or Masters level in Business Administration whose earlier qualifications and experience come from a different discipline.

It is written from an Economics perspective and draws on notions of opportunity costs, resources, transactions and competition as sources of inspiration for strategic thought, in a world of uncertainty in which our attempts to behave rationally are bounded by our limited understanding. But this is not an Economics textbook and it does not assume any prior knowledge of Economic Theory. A nodding acquaintance might help with some passages but it is never essential.

I believe that every student of business, and indeed everyone who works in business, needs to know what strategy is and why it is important. They need to understand what their organisation is trying to do, and why. They may not be strategists but, if their organisation has any pretensions to good management, they should be prepared to contribute ideas to the formulation of strategy. That belief determines the focus of this book, but there are two things which the book does not try to do. It is not concerned with the implementation of strategy and it does not go into any detail on technical subjects like Business Finance. These topics are important - many good strategies will fail if they are not properly implemented, and Business Finance is an essential component of the higher strategist's art. But logically these topics come after the groundwork of a general understanding has been 
laid. Push them too soon, and the ultimate objectives may be lost in a welter of technical detail.

The book therefore aims to encourage thinking before application, and the examples look for lessons which can be applied as readily in a global setting as they can within specific national boundaries. Many of the topics are as applicable to not-for-profit organisations as they are to business enterprises. Universities, theatres, museums, charities and similar bodies all face strategic problems. Universities must position themselves in relation to other educational institutions and research bodies; theatres and museums must determine their focus and the extent of any collaboration with others; and charities must understand the logic of their target market. But the problem with not-for-profit organisations is that so much of their experience is sui generis. A depth of local knowledge is needed before the strategic choices can be understood, and one can never be certain without further detailed knowledge that any lessons can be applied in a different context. By contrast, the spread of global competition, although incomplete, has generally served to ensure that business experience transcends national and cultural boundaries. Hence, although the analysis in this book is broadly applicable to all strategic decisions, the examples have been taken only from business and commerce in order to ensure that they are as generalisable as possible.

Many of these examples come from books or articles, or from unascribed reports in periodicals like The Economist, or from company reports. These sources are acknowledged in the text. Other examples have been put together from a variety of different sources and in these cases no specific references can be given. For all these examples, I acknowledge my debt to the named or anonymous writers on whose work I have drawn. Further, in a few cases the published information has been supplemented by additional information provided by the companies concerned, and in these cases especially BAA, Manx Airlines, Peptide Therapeutics and Thermo Electron - I am particularly grateful to the organisations and to the individuals concerned for their help, although of course any errors or omissions in the text are entirely of my own making.

Thanks are also due to the staff of the Isle of Man College Library, and especially to Tim Kenyon, for patient and unfailing support for my efforts to trace references through the British Lending Library.

Among the many colleagues and students who have influenced my own strategic thinking there are two who deserve special mention. I must record special thanks to Peter Jackson who first suggested that this might be worth doing, and to my wife Dorothy whose patience helped to ensure that it could be done.

Clive Sutton

Every effort has been made to contact all copyright-holders but if any have been inadvertently omitted then the publishers will be pleased to make the necessary arrangements at the earliest opportunity. 